RESEARCH PAPER

\title{
Tobacco industry litigation to deter local public health ordinances: the industry usually loses in court
}

\author{
M L Nixon, L Mahmoud, S A Glantz
}

Tobacco Control 2004; 13:65-73

See end of article for authors' affiliations

.....................

Correspondence to: Stanton A Glantz, PhD, Box 1390, University of California, San Francisco, San Francisco, CA 941431390, USA:

glantz@medicine.ucsf.edu

Received 28 March 2003 Accepted 9 September 2003

\begin{abstract}
Background: The tobacco industry uses claims of state preemption or violations of the US Constitution in litigation to overturn local tobacco control ordinances.

Methods: Collection of lawsuits filed or threatened against local governments in the USA; review of previously secret tobacco industry documents; interviews with key informants.

Results: The industry is most likely to prevail when a court holds that there is explicit preemption language by the state legislature to exclusively regulate tobacco. The industry has a much weaker record on claims of implied preemption and has lost all challenges brought under equal protection claims in the cases we located. Although the tobacco industry is willing to spend substantial amounts of money on these lawsuits, it never won on constitutional equal protection grounds and lost or dropped $60 \%$ (16/27) of the cases it brought claiming implied state preemption.

Conclusions: Municipalities should continue to pass ordinances and be prepared to defend them against claims of implied preemption or on constitutional grounds. If the ordinance is properly prepared they will likely prevail. Health advocates should be prepared to assist in this process.
\end{abstract}

$\mathrm{S}$ ince the late 1970s, when communities in the USA began passing local tobacco control ordinances, the tobacco industry has used litigation to deter them, often through surrogates or front groups, ${ }^{12}$ including hospitality associations. ${ }^{3-5}$ The tobacco industry has occasionally revealed its financial backing of these lawsuits to intimidate local governments. ${ }^{67}$ The primary basis for these lawsuits has been federal equal protection claims under the 14th Amendment and claims of state preemption of local ordinances.$^{8-11}$ There are two broad categories of pre-emption. Explicit preemption occurs when specific preemptive language is written into the law. Implied preemption occurs when Congress or a state legislature enacts legislation that is later interpreted by courts to occupy the entire field being regulated and, therefore, precludes local regulation. As tobacco control advocates have become adept at defeating expressly preemptive legislation, the tobacco industry has turned to claiming implied preemption. ${ }^{9}$

Despite its substantial legal resources, the tobacco industry has not fared well in challenging local ordinances in court. In the cases we located, it has never won on constitutional equal protection grounds and lost or dropped $60 \%$ (16/27) of the cases it brought claiming implied state preemption. The outcomes of these lawsuits depend on not only how well an ordinance was crafted with regard to possible preemption, but also whether a community is willing to commit the financial resources to defend the ordinance and how much assistance public health agencies are willing to provide.

\section{METHODS}

We obtained information from the tobacco industry document sites available on the internet, newspaper articles, the American Nonsmokers' Rights Foundation Tobacco Industry Tracking Database, public documents, and published court decisions. ${ }^{12}$ Search terms included "lawsuit", "litigation", smoking ordinance", and community names. We interviewed city attorneys, government officials, and public health advocates in accordance with a protocol approved by the local Committee on Human Subjects.
We did not include litigation related to advertising because those cases are about express federal preemption on cigarette advertising. We also excluded cases against boards of health because these cases often involve purely procedural issues, such as whether the board has the authority to pass a regulation or whether they used the right process in doing so. This paper focuses on substantive legal questions, and the board of health cases have been discussed at length elsewhere. ${ }^{4}$

\section{RESULTS}

We identified 28 communities where a local government had passed tobacco control ordinances that were challenged in court or where legal challenges were threatened between 1987 and 2003 (table 1). While we sought to include all cases, there may be additional unreported cased that are not included. Those cases selected for study were chosen because they were representative of the most common legal strategies used against these ordinances. Many other cases involved procedural issues or unique situations which did not lend themselves to a quantitative analysis. While we only discuss a few cases in detail, the successful strategies used by many of these communities will be applicable elsewhere.

Of the ordinances selected, 14 were upheld, nine were overturned and four were amended or rescinded to avoid the lawsuit. Of these four amended ordinances, two were only weakened slightly and two were substantially weakened. One suit was pending as of September 2003. In 15 of these cases, there was conclusive proof of links between the plaintiffs and the tobacco industry through funding of the lawsuit, front groups, or tobacco industry lawyers representing the plaintiffs.

In seven of the nine ordinances overturned in court the plaintiffs used arguments of preemption. Plaintiffs were not successful using equal protection or due process arguments derived from the Fourteenth Amendment. In three equal protection cases and three out of the four due process cases, the courts rejected the plaintiffs arguments that their 14th Amendment rights were violated by passage of a public health ordinance and declared that local governments have 


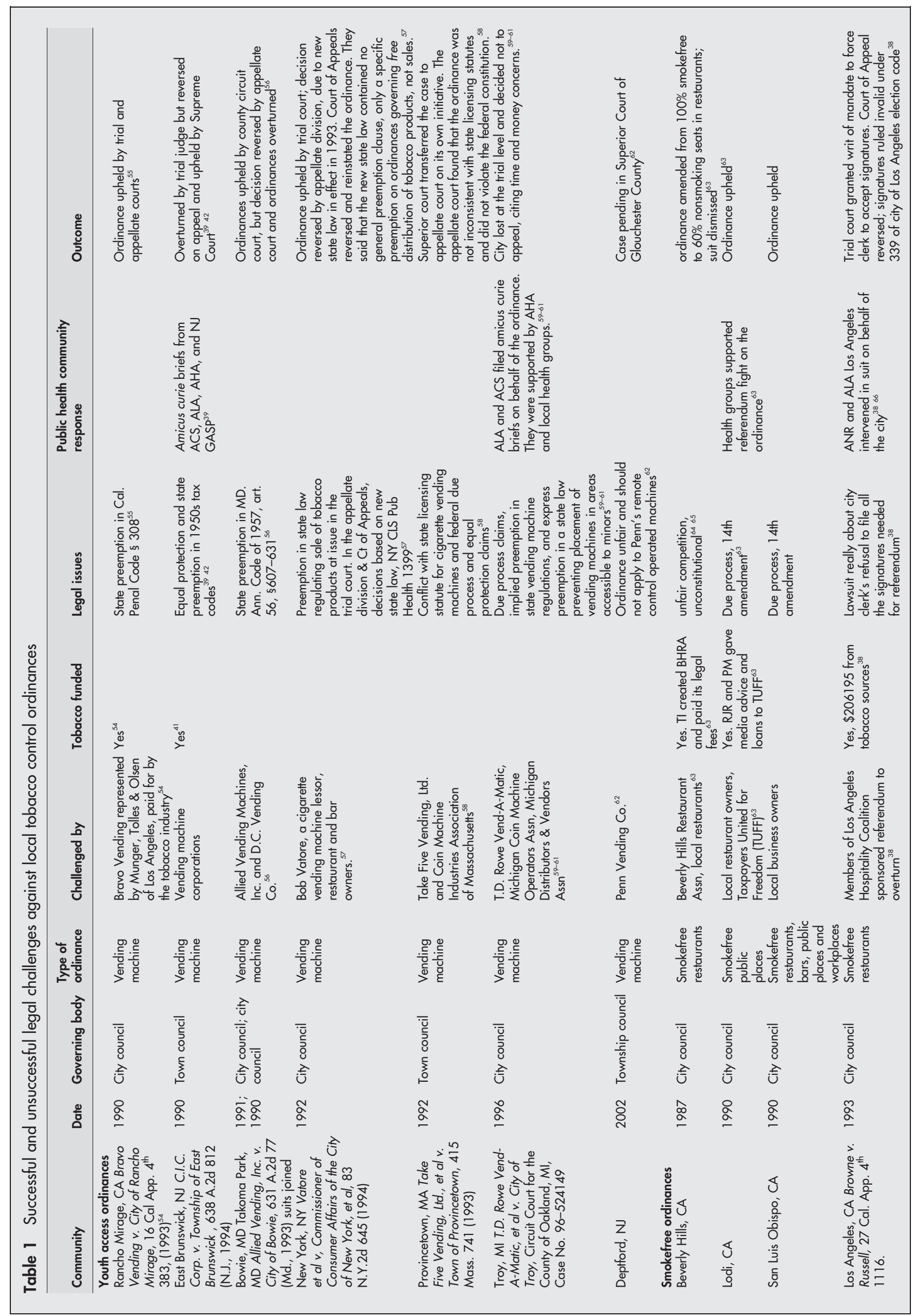



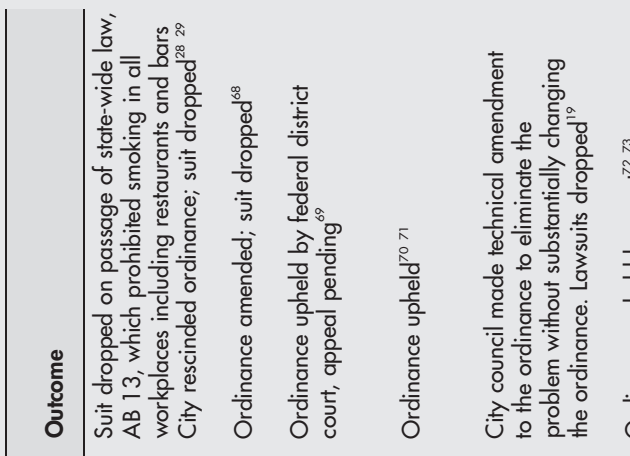

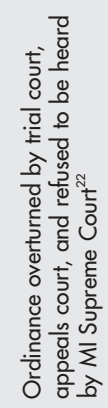

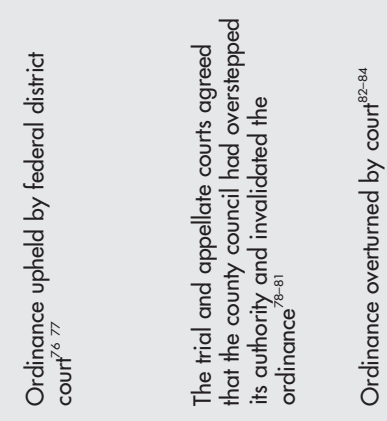

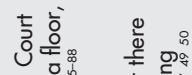

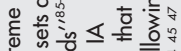

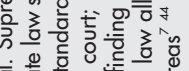

可产

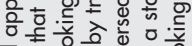

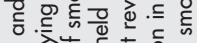

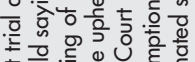

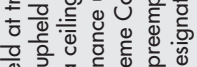

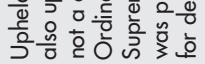

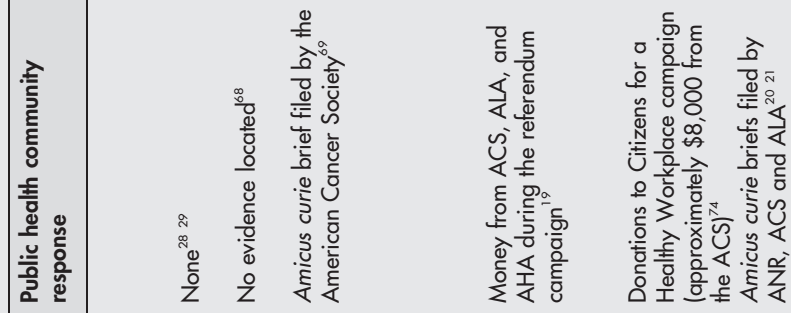

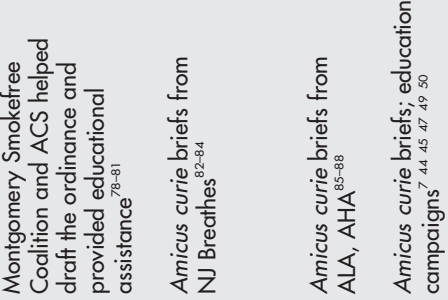

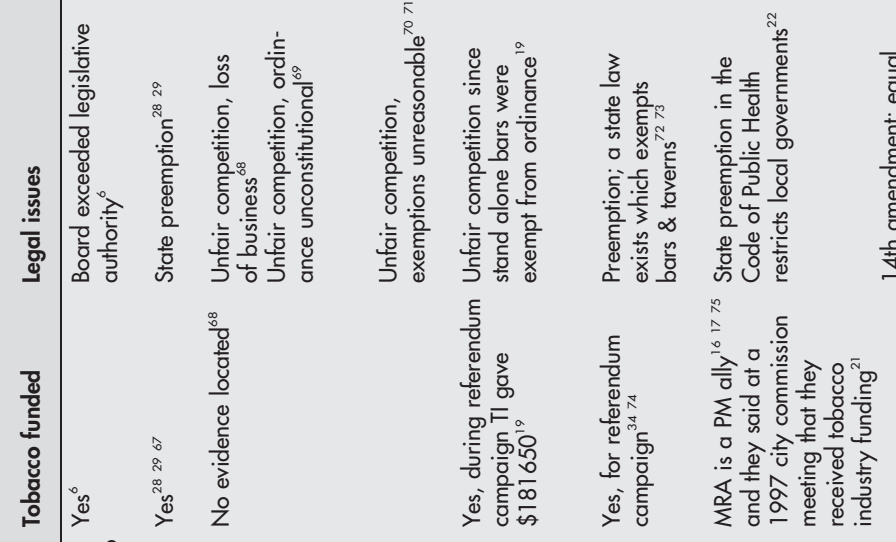

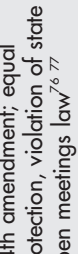

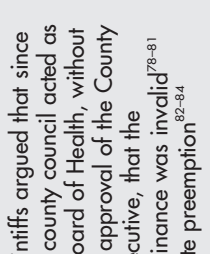

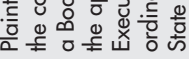

z)

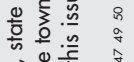

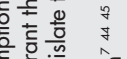

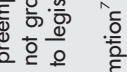

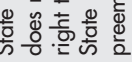

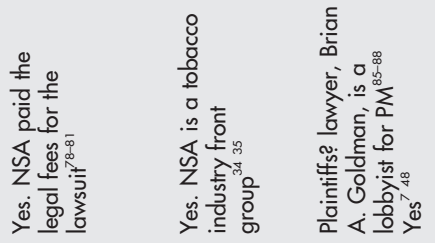

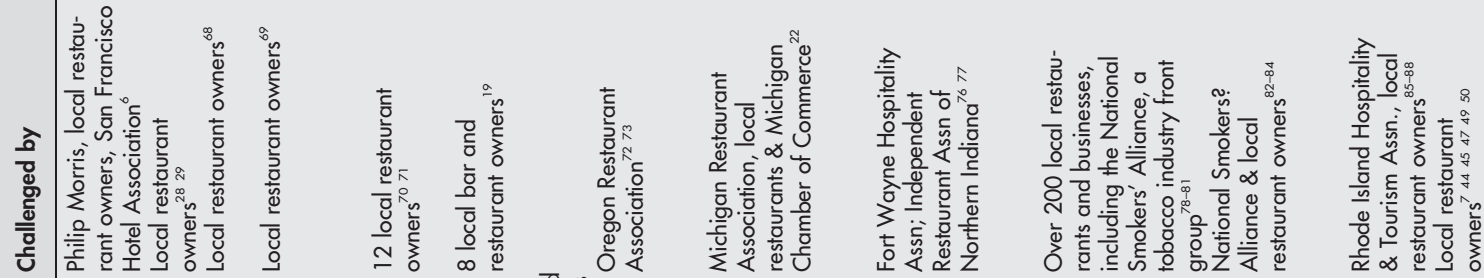

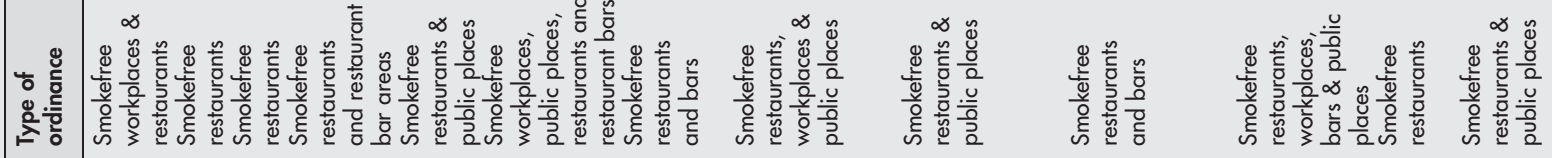

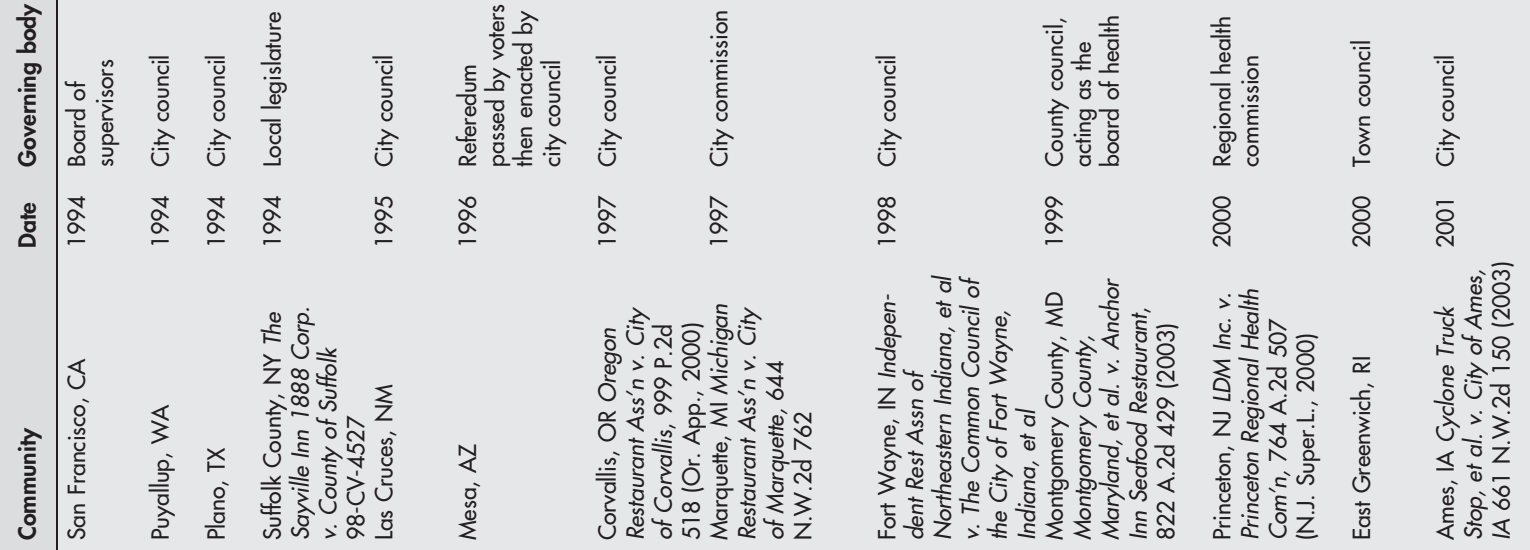




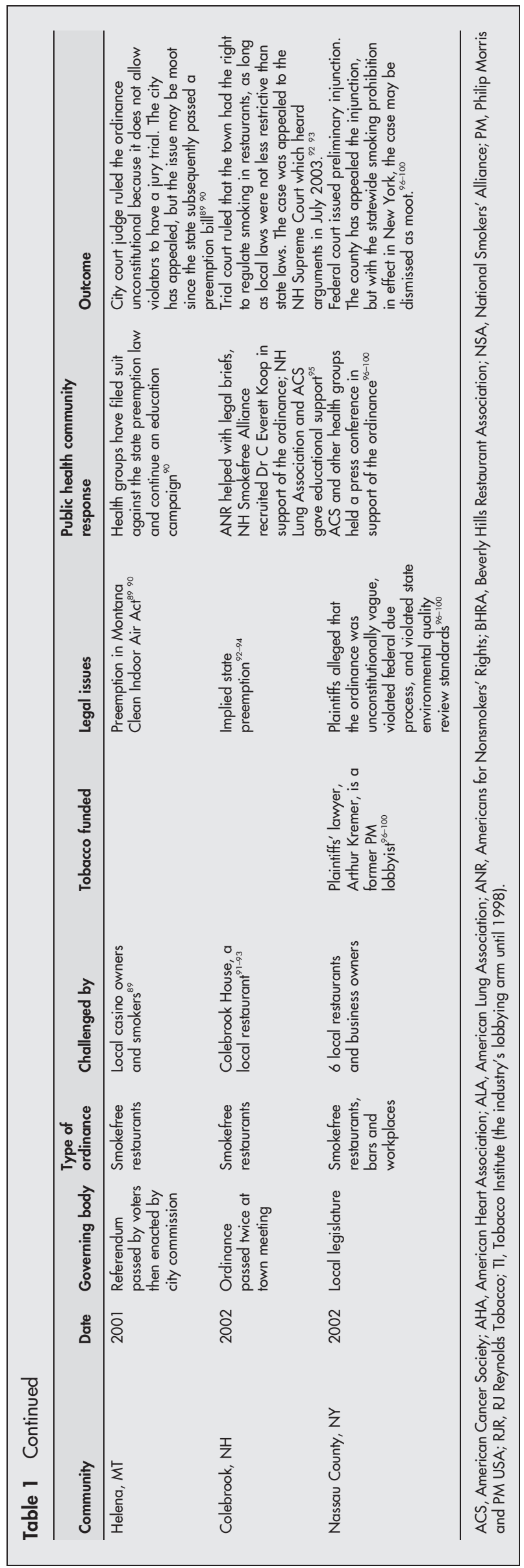

the right to protect public health. Plaintiffs also made five unfair competition claims, but they lost three of these in court.

We selected six of these 28 cases that represent the legal strategies the industry used to challenge smokefree ordinances and the efforts of health advocates to defend them.

\section{Marquette, Michigan}

In 1997, Marquette, Michigan (population 22 000) began considering strengthening its 10 year old local clean indoor air ordinance. The Michigan Restaurant Association (MRA) opposed the new ordinance while receiving tobacco industry money. Harry Klingeman, the Association's Government Affairs Director, threatened litigation if the ordinance was passed based on unsubstantiated predictions ${ }^{13}{ }^{14}$ that "Marquette restaurant sales will drop about 20 percent should the commission toughen its ...anti-smoking ordinance". ${ }^{15}$ The MRA website lists Philip Morris as a 2002 Platinum Sponsor as well as the Philip Morris "Options Program" as a Diamond Sponsor. Its website also includes a page on "Indoor air quality and ventilation" sponsored by the Options Program, including a link to it. ${ }^{16}$

On 25 June 1997, Klingeman sent a letter to the Marquette City Commission and later sent a copy to Philip Morris advocating a voluntary programme for smoking in the city's restaurants. The association's plan included changing the size and location of non-smoking sections, posting signs throughout the smoking section saying, "Please be considerate of your non-smoking friends," and posting signs at the entrance to a restaurant announcing if the establishment allowed smoking. The letter also repeated unsubstantiated tobacco industry claims ${ }^{13}{ }^{14}$ that other communities, particularly Mesa, Arizona, had suffered negative economic effects after initiating restaurant smoking restrictions. ${ }^{17}$ (In fact, tax data from Mesa show that the ordinance was associated with significantly higher restaurant sales. ${ }^{18}{ }^{19}$ )

On 28 July 1997, the City Commission adopted a comprehensive ordinance that prohibited smoking in most public places including all enclosed workplaces and restaurants effective 1 January 1999.

The MRA, six local restaurants, and the Michigan Chamber of Commerce sued the city in December 1998 to stop the restaurant smoking restrictions. On 7 January 1999 the county circuit court ruled that the restaurant provisions of the ordinance were preempted by state law. The judge ruled that since the Michigan Public Health Code grants restaurants the right to designate part of their establishment as a smoking section, local governments are precluded from taking away this right.

The city appealed to the Michigan Court of Appeals. Americans for Nonsmokers' Rights and a coalition of the American Heart Association, American Cancer Society, and American Lung Association filed amicus curie briefs in support of the ordinance. ${ }^{20}{ }^{21}$ On 13 March 2001, the Court of Appeals upheld the lower court decision. It ruled that localities cannot totally prohibit smoking in restaurants and bars and that "the [Marquette] ordinance is in direct conflict with a food service establishment's right under MCL 333.12905(2); MSA 14.15(12905)(2) to designate a certain percentage of its seating capacity as seating for smokers. The question of whether there should be a total ban on smoking in restaurants [and bars] must be left to the legislature."22 MCL 333.12905(2); MSA 14.15(12905)(2), part of the Michigan Clean Indoor Air Act passed in 1978, specifies the maximum number of smoking seats a food service establishment may maintain.

The Court of Appeals concluded that Marquette's ordinance was in direct conflict with a food service establishment's right under state statutes that specify designation of 
up to a certain percentage of its seating capacity for smokers. The city appealed the case to the Michigan Supreme Court; on 6 May 2002 the Supreme Court refused to hear the appeal so the lower court decisions prevailed..$^{23}$

A crucial aspect of this case is that when the Marquette ordinance was challenged, the plaintiffs only opposed the provisions on smoking in restaurants; the requirement for smokefree worksites and public places, other than restaurants, have remained in effect since 1 January 1999. The absence of any challenge to the other portions of the Marquette ordinance indicates that local government authority to impose such smoking restrictions on workplaces and public places is not preempted by state law. In 2002, the Marquette and Ingham County Boards of Health introduced ordinances to prohibit smoking countywide in workplaces and public places. In keeping with the Michigan Restaurant Ass' $n$ case, they excluded bars and restaurants from these ordinances. ${ }^{24}{ }^{25}$ Workplace smoking restrictions protect more people and have a greater effect on consumption than restaurant ordinances alone. ${ }^{26}$

\section{Puyallup, Washington}

In 1994, Puyallup (population 27 000) passed the first local smokefree ordinance in Washington; it covered restaurants but excluded bars, taverns, and cocktail lounges. Public health agencies, including the American Cancer Society, Pierce County Health Department, and a majority of private citizens and restaurant owners, supported the ordinance. ${ }^{27}$ Opposition came from a smokers rights group funded by RJ Reynolds Tobacco. ${ }^{28} 29$

RJ Reynolds provided financial and legal assistance to restaurant owners who opposed the regulations. It circulated a video that highlighted the alleged negative effects of smoking restrictions, including restaurant owners who complained of lost business. RJ Reynolds also hired a camera crew to film local restaurant patrons who said that they would eat outside of the city if the ordinance was adopted. When the ordinance was initially proposed, all seven council members supported it; RJ Reynolds convinced three members to vote against the ordinance, ${ }^{28}{ }^{29}$ so it passed by a 4-3 vote in August 1994 to go into effect 1 January 1995. ${ }^{28}{ }^{29}$

In November 1994, Byrnes \& Keller, one of the largest law firms in Seattle, sued the city, the city council, and Mayor Mike Deal on behalf of nine Puyallup restaurant owners. The suit was funded by RJ Reynolds, ${ }^{30}$ and the firm had worked closely with the Tobacco Institute when it financed a case against the Washington ASSIST programme..$^{28} 31$ The restaurant owners argued that the Puyallup ordinance violated the Washington Clean Indoor Air Act which they claimed preempted local governments from surpassing its provisions. $^{28} 29$ Puyallup's City Attorney, Robin Jenkinson, reviewed the Washington Administrative Code Provisions and found nothing that would preclude the city from passing its ordinance. ${ }^{32}$

Despite their belief that the ordinance was legal, the council members soon retreated out of concern of facing a possibly expensive lawsuit. Even if they won in Superior Court, they believed that the industry would appeal the case and extend the issue for years to come and be too expensive for the city to afford. ${ }^{29}$ (This was probably an overestimate; Marquette, MI only spent $\$ 80000$ in litigation costs to carry their case all the way to the state Supreme Court. ${ }^{33}$ ) Puyallup was not offered financial or other support from any public health agencies or advocates.

To have the lawsuit dropped, the council agreed to rescind the ordinance. In addition, the city council agreed that if it ever passed another ordinance and it was found to violate the Washington Clean Indoor Air Act, the city would be liable for all the stipulated attorney's fees. ${ }^{28}{ }^{29}$ In December, 1994, the council voted 6-1 to repeal the ordinance. The city council made its decision strictly based upon the fiscal concerns of their community and the cost of litigating against the tobacco industry, not the legal merits of the ordinance. ${ }^{32}$ Since Puyallup's defeat, health advocates have asked Attorney General Christine Gregoire to issue a formal opinion about whether or not the Clean Indoor Air Act is preemptive, but she has been unwilling to do so, and health advocates have also been unwilling to enact any additional ordinances without such an opinion.

\section{Princeton, New Jersey}

On 1 June 2000 the Princeton Regional Health Commission adopted the most comprehensive smokefree ordinance in New Jersey, which prohibited smoking anywhere except private homes, cars, cigar shops, or outdoors. Local restaurants and the National Smokers Alliance (which was created by public relations firm Burston-Marsteller for Philip Morris in $1993^{34}{ }^{35}$ ) sued the Health Commission, and on 30 August 2000, a New Jersey Superior Court judge struck down the ordinance in its entirety. ${ }^{36}$ The court ruled that New Jersey law precludes a municipality from ending smoking in restaurants based on the effects of smoking on the public health. The authority of the municipality to restrict smoking in restaurants is limited to protecting life and property from fire, as stated in N.J.S.A. 26:3E-10(b). The Superior Court concluded that there is a clear intent by the New Jersey Legislature to comprehensively regulate smoking in indoor public places, and to do so exclusively. The court determined that allowing municipal smokefree restaurant ordinances would thwart the balance of the rights of smokers and nonsmokers, a balance that the Legislature sought to protect. ${ }^{36}$

Princeton did not appeal the ruling, even though groups such as the New Jersey Group Against Smoke Pollution (NJ GASP) were confident that the town could win and offered to support the appeal. According to NJ GASP, the legislative history of N.J.S.A. 26: 3E-10(b) does not show any clear intent on the part of the state legislature to completely preempt municipalities from enacting smoke-free restaurant ordinances. The law lists three separate grounds that permit municipalities to pass smoke-free restaurant ordinances: N.J.S.A. 40:48-1, 40:48-2, or any other statute to protect life and property from fire. ${ }^{37}$

Moreover, the smokefree indoor air ordinances in place in other New Jersey municipalities (Glassboro, Highland Park, Lawrence, Marlboro, and Secaucus) have not been challenged. While Princeton's ordinance was being challenged in court, Linwood passed an ordinance making all restaurants smokefree, and Pitman passed a smokefree ordinance for all public places where 10 or more people enter. Neither of these two towns has been sued. ${ }^{37}$ These situations make it puzzling that Princeton did not appeal the court ruling overturning its ordinance or simply enact a revised ordinance under the statues the court said could be applied.

\section{Los Angeles, California}

The courts can also be used by health groups to oppose the tobacco industry. In 1993, the Los Angeles Hospitality Coalition, a tobacco industry front group, sponsored a referendum to overturn a smokefree restaurant ordinance passed by the city council of Los Angeles. Of the \$211 144 to fund the referendum, \$206 195 (98\%) came from the tobacco industry. ${ }^{38}$ The Coalition hired American Petition Consultants, a firm in the business of qualifying initiatives and referenda for the ballot, to qualify a referendum seeking to repeal the ordinance. ${ }^{2}$ The city clerk rejected some of the signatures after determining that some petition circulators were not registered voters of Los Angeles, as required by city 
law, and concluded that the Coalition did not submit enough valid signatures to force the referendum vote. ${ }^{38}$

The Coalition went to court seeking a writ of mandate to force the clerk to certify the signatures and the trial court agreed on the grounds that the requirement that petition circulators be registered voters in Los Angeles violated the constitutional right of free speech. ${ }^{38}$

Los Angeles appealed and the Court of Appeal reversed the trial court's decision, holding that the lower court erred in ordering the city to count the signatures on petitions circulated by non-residents, since the city had compelling interests that were protected by the ordinance requiring petition circulators to be residents and registered voters of the city. ${ }^{38}$ An important part of the success of this case on appeal was due to the legal and financial assistance of Americans for Nonsmokers' Rights and the American Lung Association of Los Angeles County, both formal interveners. ${ }^{38}$

\section{East Brunswick, New Jersey}

On 27 June 1990, East Brunswick Mayor Jack Sinagra proposed an ordinance to the town council to eliminate cigarette vending machines. At a public hearing on the ordinance, supporters included New Jersey GASP, local high school students and Parent Teachers Associations, and Dr John Slade of the Robert Wood Johnson Medical School and the Department of Medicine at St Peter's Medical Center. The students who attended the meeting testified that cigarettes were readily available and easy to obtain from vending machines. ${ }^{39}$

Opponents included local vending machine companies that argued that the ordinance would drive them out of business and make their machines worthless. (In February 1991, Philip Morris conducted an analysis which described how the tobacco industry could be adversely affected by vending machine ordinances, even though cigarettes only accounted for $6 \%$ of total vending machine sales and had been in decline since the mid-1980s. ${ }^{40}$ ) On 9 July 1990 the council voted unanimously for the ordinance. Several vending machine companies sued the town to prevent the ordinance from going into effect. The named plaintiffs in the suit were the C.I.C. Corporation, Coast Cigarette Sales, Eskin Vending Corporation, and the Amusement and Music Operators Association, ${ }^{39}$ who reportedly accepted financial support from the tobacco industry. ${ }^{41}$

The town council, the Mayor and Town Attorney Bertram Busch decided to defend their ordinance despite concerns that costs of litigation could be considerable. Busch, whose position with the town was only part time, volunteered to pursue the case with the help of the associates in his private firm and for a discounted rate, which persuaded the town government that the costs of the lawsuit would not be prohibitive. ${ }^{39}$ The town was also bolstered by offers of informational assistance from GASP, Slade, the Tobacco Products Liability Project in Boston, Massachusetts, and letters of support from the American Cancer Society, American Lung Association, and the American Heart Association. ${ }^{39}$

The plaintiffs claimed that the ordinance violated equal protection by drawing an arbitrary and unreasonable distinction between the sale of cigarettes from vending machines and over-the-counter cigarette sales, and that the township was preempted from enacting the ordinance under New Jersey's Cigarette Tax Act of 1954 (NJSA 54:40A-1 to 45 ) and the Unfair Cigarette Tax of 1956 (NJSA 56:7-18 to 38), which establish the state's tax on cigarette vending machines. Since these taxes are a source of revenue for the state, the plaintiffs argued, then the state is exclusively responsible for regulating vending machines. The trial judge in Superior Court rejected the plaintiff's constitutional claims but ruled in favour of their state preemption arguments. ${ }^{42}$

The Mayor and the City Council appealed. The Appellate Court heard the case on 1 June 1993, almost two years after the ordinance was first passed. In support of the town, amicus curiae briefs were submitted by New Jersey GASP, the Action on Smoking and Health, American Heart Association, American Lung Association, and the American Cancer Society. ${ }^{39}$ The Appellate Court ruled in favour of the town and reversed the lower court ruling. ${ }^{42}$

According to the Appellate Court, the mere fact of subject convergence is not by itself determinative of the preemption question. In evaluating a state preemption argument in the absence of an expressed preclusion of municipal authority, a court must carefully examine in detail the actual ways in which state and municipal ordinances conflict. Upon reviewing the Cigarette Tax Act and the Unfair Cigarette Sales Act, the appellate court declared that neither was an expression of complete or exclusive regulation of the use of cigarette vending machines. The court held that there is no legislation which clearly intends to be exclusive with respect to cigarette vending machines or with which the East Brunswick ordinance conflicts. Sale of cigarettes to minors within the borders of a municipality is a matter of municipal concern that can be regulated on a local basis. ${ }^{42}$ The vendors appealed to the State Supreme Court, which affirmed the appellate decision and upheld the ordinance in March 1994. ${ }^{42}$

\section{Ames, lowa}

Ames, home to Iowa State University, began to consider a smokefree restaurant law in August 2000. ${ }^{43}$ Ordinance advocates were willing to accept an ordinance that exempted bars and only required smokefree restaurants before 8.30 pm. ${ }^{44}$ Nevertheless, opponents claimed that state law preempted the ordinance, so ordinance supporters consulted with the Iowa Attorney General's office, which issued an opinion that local governments are not preempted from passing smokefree ordinances because the Iowa Code "expressly recognizes the authority of local jurisdictions to pass ordinances prohibiting smoking in some public places in which state law would permit smoking". ${ }^{45}$ Specifically, Chapter 142B.2(2) of the Iowa Code (the Iowa Clean Indoor Air Act passed in 1987 and amended in 1990) addresses preemption. This provision specified the mechanics of designating smoking areas within public places. In doing so, it expressly recognises the authority of local jurisdictions to pass ordinances prohibiting smoking in some public places in which state law would permit smoking.

Ames enacted the compromise plan in March 2001 to go into effect on 1 August 2001. ${ }^{46}$ Between 1 August and 25 September 2001 the ordinance was in effect and compliance rates were high. Ted Tedesco, Mayor of Ames, was taken by surprise when several local restaurants filed suit against the ordinance. ${ }^{47}$

The named plaintiffs in the case, Cyclone Truck Stop, Wallaby's, Dublin Bay, Café Baudelaire, Tradewinds Case, Whiskey River, and People's Bar and Grill, argued that an Iowa law which ordered fines for smoking in a non-smoking section of a restaurant was proof that the state allowed for smoking in designated areas. The plaintiffs asked that the ordinance be enjoined until the case was decided.

Meanwhile, Philip Morris announced that it would fund the lawsuit against the city after a request for assistance from the restaurant owners. PM USA spokesperson Billy Abshaw stated that "[PM] believes in business owner choice... As they made the request to us, we decided this meets our business objectives". ${ }^{7}$ He also revealed that Philip Morris has funded similar suits. "This isn't an isolated incident," he said. "We certainly review these things on a case-by-case basis." ${ }^{48}$ 
In February 2002, Judge Carl Baker rejected the plaintiffs' claims of preemption, ruling that "the legislature has not specifically stated that smoking prohibitions cannot be the subject of local action" and that "the [Ames] ordinance does not permit what the statute prohibits, nor does it prohibit what the statute permits". ${ }^{49}$ The restaurant owners appealed to the Supreme Court, which issued its decision on 7 May 2003.

The Supreme Court reversed the decision of the trial court, finding that the Ames ordinance was preempted by the provisions in the Iowa Code that allowed for designated smoking areas (142B.2) and which superseded any local regulation that was inconsistent with that provision (142B.6). ${ }^{50}$ The court granted an injunction to prohibit Ames from enforcing its ordinance. This decision also affected a similar ordinance in Iowa City. The end result is that tobacco control advocates must return to the state legislature to remove the preemption. In May 2003, Iowa Attorney General Tom Miller called on the Legislature to revise the state law to allow local communities to enact tobacco control ordinances. ${ }^{51}$

\section{DISCUSSION}

Despite the tobacco industry's well earned reputation as a ferocious litigator, the fact is that the industry (and its front groups and allies) has not fared well when using the courts to challenge local tobacco control ordinances. Indeed, it lost or dropped $60 \%(16 / 27)$ of the contested cases (table 1 ).

The industry uses arguments of equal protection and implied preemption. The industry has never prevailed on equal protection arguments, but has prevailed in some cases on implied preemption when state law specifically grants restaurants or business owners the right to designate smoking areas, even without an explicit preemption clause. The tobacco industry can find justification for claims based upon implied preemption almost anywhere, in decades old cigarette vending machine legislation, and in state laws providing fines for smoking in non-designated areas. Occasionally these arguments have prevailed, but most often they have not.

While the tobacco industry's reputation for filing appeals has been used to intimidate local governments from enacting local ordinances (as in Puyallup), the fact remains that localities have also succeeded in overturning adverse rulings on appeal. Localities enacting tobacco control ordinances should anticipate litigation and plan to appeal any adverse rulings to the state supreme court, if necessary.

The importance of these initial legal battles over local ordinances cannot be overstated. Puyallup's decision to rescind rather than defend its local smokefree restaurant ordinance deterred other communities from attempting to regulate smoking in their restaurants, despite the fact that there has never been a definitive court ruling on the precise meaning of the language in the Washington state Clean Indoor Air law. The ramifications of East Brunswick's successful defence of its ordinance on appeal were immediate. In the year following the Supreme Court decision, 153 local ordinances were enacted in New Jersey dealing with youth access or clean indoor air, compared to 19 ordinances passed in the year before the decision. Contrasting this situation to the one in Puyallup, we can see how one community, when they decide to fight back against the tobacco industry and its allies, can effect great change. Even in cases where the locality loses, such as in Marquette, this process is worthwhile because it clarifies the precise meaning of the law. While Marquette lost on the issue of smokefree restaurants, the case clarified the right of localities to enact and enforce smokefree workplace and public places legislation, which itself is a worthwhile policy. ${ }^{26}$
What this paper adds

The tobacco industry has a reputation of being a ferocious litigator, using procedural manoeuvres to run up the cost of litigation and drag out the process. The industry often threatens or actually sues local communities in the USA when they are the first place to enact local tobacco control legislation in a given state.

In contrast to the situation in smoking and health litigation, which includes extensive discovery, these cases are resolved quickly and at low cost. More important, the industry has lost $60 \%$ of the cases surveyed here. Local government bodies should anticipate this litigation when they are the first community to enact tobacco control legislation and should be prepared to defend the laws through the appeals process. Tobacco control advocates can facilitate this process by providing technical assistance to local communities.

In some cases the courts provide guidance on how to deal with claims of implied state preemption. In the Princeton, New Jersey case, ${ }^{36}$ the court expressly ruled that localities could regulate smoking in restaurants and bars to protect life and property from preventable fires under N.J.S.A. 26:3E10(b) rather than to control secondhand smoke. (Smoking is the number one preventable cause of fires in the USA. ${ }^{52}$ ) The fact that Princeton did not appeal the ruling on implied preemption grounds has left the issue clouded, particularly since other communities in New Jersey have enacted local ordinances restricting smoking in restaurants without legal challenge.

Municipalities should not fear the cost of lawsuits: preemption suits do not have high litigation costs, because discovery-which the tobacco industry uses to impose high financial and time costs on plaintiffs-is not a major element in these types of lawsuits. These cases are resolved on the law and relatively quickly. The Marquette case, which went all the way to the state supreme court, only cost $\$ 80000 .^{33}$ In the case of Ames, Iowa, one attorney working part time defended an implied preemption suit. These costs are less than a city may incur in a lawsuit contesting property taxes. ${ }^{53}$ In any event, absent express preemption in state law, local governments should keep passing local tobacco control ordinances regardless of tobacco industry threats of litigation; they should be ready to defend these ordinances, through the appeals process, if necessary. Active support from public health groups can support efforts of local communities, as in East Brunswick, by providing material assistance to communities during this process.

This litigation phenomenon should not be seen as unique to the USA. With the passage of the Framework Convention on Tobacco Control and the initiation of stricter international tobacco control laws, other countries should be prepared to deal with litigation as they begin to pass clean indoor air ordinances.

The tobacco industry clearly recognises the importance of this litigation; public health advocates should anticipate it and prepare accordingly rather than accept industry claims of implied preemption.

\section{ACKNOWLEDGEMENTS}

This work was supported by National Cancer Institute grants CA61021 and CA-87472.

\section{Authors' affiliations}

M L Nixon, L Mahmoud, S A Glantz, Center for Tobacco Control Research and Education, University of California, San Francisco, San Francisco, California, USA 


\section{REFERENCES}

1 Samuels B, Glantz SA. The politics of local tobacco control. JAMA $1991 ; 266: 2110-7$

2 Traynor MP, Begay ME, Glantz SA. New tobacco industry strategy to prevent local tobacco control. JAMA 1993;270:479-86.

3 Dearlove JV, Bialous SA, Glantz SA. Tobacco industry manipulation of the hospitality industry to maintain smoking in public places. Tobacco Control 2002;11:94-104.

4 Dearlove JV, Glantz SA. Boards of Health as venues for clean indoor air policy making. Am J Public Health 2002;92:257-65.

5 Ritch WA, Begay ME. Strange bedfellows: the history of collaboration between the Massachusetts Restaurant Association and the tobacco industry. Am J Public Health 2001;91:598-603.

6 Leary K. Strict New SF ordinance: smokers pushed farther out by lawmakers. San Francisco Chronicle 1994 March;24:A1.

7 Associated Press. Judge to rule soon on halting smoking ordinance. Associated Press, 3 October 2001.

8 Siegel M, Carol J, Jordan J, et al. Preemption in tobacco control. Review of an emerging public health problem. JAMA 1997;278:858-63.

9 Hobart R. Preemption: Taking the local out of tobacco control. Smokeless states national tobacco policy initiative: American Medical Association; 2002, www.ama-assn.org/ama/upload/mm/375/preemption_guide.pdf.

10 Centers for Disease Control. Preemptive state tobacco control laws - United States, 1982-1998. MMWR Morb Mortal Wkly Rep 1999;47:1 $112-14$

11 Walls T. CAC Presentation \#4, draft 7/8/94. 1994. Bates No. 041183751 3790. egacy.library.ucsf.edu/tid/vnf77e00

12 Malone RE, Balbach E, eds. Tobacco industry documents: treasure trove or quagmire? Tobacco Control 2000;9:334-8

13 Glantz SA. Smoke-free restaurant ordinances do not affect restaurant business. Period. J Public Health Manag Pract 1999;5(1):vi-ix.

14 Scollo M, Lal A, Glantz S. Why studies of the economic effects of smoke-free policies on the hospitality industry reach different conclusions. Tobacco Control 2003; 12:13-20.

15 Sargent B. Restaurant group may sue city if ban $\mathrm{Ok}^{\prime} \mathrm{d}$. The Mining Journal, 1997 May, 28:1A.

16 Michigan Restaurant Association. Homepage. www.michiganrestaurant.org Accessed 20 November 2002

17 Klingeman H. [Letter to City Commissioners, Marquette MI]. 1997. Bates No. 2072340672A_0674. legacy.library.ucsf.edu/tid/cmd08d00.

18 Glantz S, Smith L. The effect of ordinances requiring smoke-free restaurants on restaurant sales. Am J Public Health 1994;84:1081-5.

19 Bialous S, Glantz S. Tobacco Control in Arizona, 1973-1997. IHPS Monograph Series. San Francisco: University of California, San Francisco, Institute for Health Policy Studies, School of Medicine, 1997 October. repositories.cdlib.org/ctcre/tcpmus/AZ1997.

20 Americans for Nonsmokers' Rights, amicus curie brief. Michigan Restaurant Ass'n v. City of Marquette. Docket \#21732: Michigan Court of Appeals, 20 July 1999.

21 Harrington J, (Marquette County Health Department). Personal Interview with Meredith Nixon. 2002

22 Michigan Restaurant Ass'n v. City of Marquette, 644 N.W.2d 762 (2001).

23 Michigan Restaurant Association. Michigan Restaurant Association: Marquette Smoking Ban Snuffed Out. Press Release: Michigan Restaurant Association; Accessed 12 June 2002.

24 Associated Press. Michigan members take their turn. Associated Press, 1 April 2002.

25 Associated Press. Upper Peninsula Briefs. Associated Press, 24 October 2002.

26 Fichtenberg CM, Glantz SA. Effect of smoke-free workplaces on smoking behaviour: systematic review. BMJ 2002;325:188.

27 Deal M. Council Member, Puyallup, WA. Interview with Meredith Nixon. 2000.

28 Nixon M, Glantz S. Tobacco Industry Political Activity and Tobacco Contro Policy Making in Washington: 1996-2000. IHPS Monograph Series. San Francisco: University of California, San Francisco, Institute for Health Policy Studies, School of Medicine; March 2001, repositories.cdlib.org/ctcre/ tcpmus/WA2001.

29 Monardi F, Glantz S. Tobacco industry political activity and tobacco control policy making in Washington, 1983-1996. IHPS Monograph Series. San Francisco: University of California, San Francisco, Institute for Health Policy Studies, School of Medicine, November 1996, repositories.collib.org/ctcre/ tcpmus/WA1996.

30 Staff. Puyallup ban goes up in smoke after tobacco financed lawsuit. Tacoma News Tribune 20 December 1994

31 Bialous SA, Fox BJ, Glantz SA. Tobacco industry allegations of "illegal lobbying" and state tobacco control. Am J Public Health 2001;91:62-7.

32 Jenkinson R. City Attorney, Tacoma, WA. Interview with Meredith Nixon. 2000.

33 Sargent B. City smoking law uncertain. Mining Journal 18 May 2002.

34 American Nonsmoker' Rights Foundation. National Smokers Alliance Exposed: A Report on the Activities of Philip Morris' \#1 Front Group: American Nonsmokers' Rights Foundation; 1999. www.no-smoke.org.

35 Philip Morris. Additional items for discussion. Bates No. 2045741537_1539. legacy.library.ucsf.edu/tid/fbl16e00.

36 LDM Inc. v. Princeton Regional Health Com'n, 764 A.2d 503 (2000).

37 New Jersey GASP. "After Princeton, What Can Municipalities Do About Tobacco?" 2000. www.njgasp.com/ł3_pton.htm Accessed 17 December 2002.

38 Browne v. Russell 27 Cal.App.4th 1116 (1993).
39 Monardi F, Glantz S. Tobacco industry political activity and tobacco control policy making in New Jersey, 1982-1995. IHPS Monograph Series. San Francisco: University of California, San Francisco, Institute for Health Policy Studies, School of Medicine, May 1997. repositories.collib.org/ctcre/tcpmus/ NJ1997.

40 Philip Morris. Vending Trade Class Review. February 1991. Bates No. 2042398306_8325. legacy.library.ucsf.edu/tid/bqv62e00.

41 Bird L. Cigarette Machine Operators are Asking Clinton for Change. Wall Street Journal 1995:A3-4.

42 CIC Corp v Township of East Brunswick 638 A.2d 756 (1994).

43 Associated Press. Ames may ban smoking in restaurants. Associated Press, 15 August 2000

44 Associated Press. Restaurant owners present compromise smoking ban. Associated Press, 10 November 2000.

45 Associated Press. AG's office says Ames is not out of line with smoking ban. Associated Press, 14 November 2000.

46 Associated Press. Several lowa cities considering smoking bans. Associated Press, 4 June 2001

47 Associated Press. Seven restaurant owners file lawsuit against Ames. Associated Press, 26 September 2001.

48 Hupp S. Tobacco concern will back lawsuit against Ames. Des Moines Register, 3 October 2001.

49 Associated Press. Smoking ban survives legal challenge. Associated Press, 14 February 2002.

50 Cyclone Truck Stop, et al v. City of Ames 661 N.W.2d 150 (2003)

51 Miller T. Press Release: Change lowa Law to protect lowans' Health, 7 May 2003

52 Leistikow BN, Martin DC, Milano CE. Fire injuries, disasters, and costs from cigarettes and cigarette lights: a global overview. Prev Med 2000:31(2 Pt 1):91-9.

53 Klaus J. Ames City Attorney. Interview with Leila Mahmoud. 2002.

54 Levin M. Fighting Laws on Smoking with Proxies; Retailing: Tobacco Companies quietly fund the battle against restrictions, opponents say. Los Angeles Times 5 August 1991:D1.

55 Bravo Vending v. City of Rancho Mirage, 16 Cal.App.4th 383 (1993)

56 Allied Vending, Inc. v. City of Bowie, 631 A.2d.77 (1993)

57 Vatore et al v. Commissioner of Consumer Affairs of the City of New York, et al, 83 N.Y.2d 645 (1994).

58 Take Five Vending, Ltd, et al v. City of Provincetown 415 Mass. 741 (1993).

59 PR Newswire Association. Health Groups Support Try City Council and Vending Machine Ban. 11 July 1996.

60 PR Newswire Association. Health Groups Disappointed with Ruling on Troy Vending Machine Ordinance. 29 July 1996

61 Letzmann P. Former Troy, MI City Attorney. Personal Communication with Meredith Nixon 2003.

62 Associated Press. News in brief from around New Jersey. Associated Press, 31 May 2002.

63 Glantz S, Balbach E. Tobacco war: inside the California battles, In: Berkeley, California: University of California Press, 2000:157-81.

64 Matthews J. No butts about it; Beverly Hills smoking ordinance takes effect. Washington Post 4 April 1987:C9.

65 Cook A. Smoking bans ignite legal brushfires. National Law Journal 1987; (11 May):3.

66 American Lung Association of Los Angeles County, Americans for Nonsmokers Rights. Application for Intervenor Status. 1993. http:// legacy.library.ucsf.edu Accessed 24 December 2002.

67 Carter D. Puyallup council reverses itself and snuffs out no-smoking law. Seattle Post-Intelligencer 12 December 1994.

68 Nixon M, Glantz S. Tobacco industry political activity and tobacco control policy making in Texas: 1980-2002. IPHS Monograph Series. San Francisco: University of California, San Francisco, Institute for Health Policy Studies, School of Medicine, May 2002, repositories.cdlib.org/ctcre/tcpmus/ TX2002.

69 Anderson C. Suffolk's ban on restaurant smoking upheld. New York Law Journal 4 August 1998:1

70 Wire Services. Complaint filed over anti-smoking ordinance. Albuquerque Journal 5 June 1996:C3.

71 Wire Services. Cruces Smoking Ban Challenge Rejected. Albuquerque Journal 28 February 1997: C3.

72 Steves D. Corvallis Ore. Bars feel few ill effects from smoking ban. The Register Guard 19 November 1999.

73 Beggs C. Corvallis smoking law challenge heard. Associated Press 19 March 1999

74 Associated Press. Tobacco companies heavy donors in Corvallis smoking ban issue. Associated Press, 31 October 1998.

75 Rizzo R. Decision in Marquette smoking ban suit. 1999. Bates No. ITI17160006. legacy.library.ucsf.edu/tid/exb50c00

76 Associated Press. Judge refuses to grant injunction against smoking ordinances. Associated Press, 13 May 1999.

77 Associated Press. Groups challenge city's smoking ban. Associated Press, 11 February 1999

78 Wilson S. Montgomery smoking ban overruled; decision seen as a big win for the tobacco industry. The Washington Post 17 June 2000:B01.

79 Wilson S. Montgomery Council to appeal ruling on smoking ban. The Washington Post 21 June 2000:A10.

80 Ruane M. Lawsuit challenges smoking ban; restaurant group, others seek to overturn Montgomery Law. The Washington Post 20 May 1999:B05. 
81 Montgomery County, Maryland, et al. v. Anchor Inn Seafood Restaurant, et al, 822 A.2d 429 (2003).

82 Thompson J. Judge shoots down Princeton smoking ban; Strictest regulations in New Jersey ruled to be in violation of state law. The Record (Bergen County) 30 August 2000:L7.

83 Toutant C. Smoke gets in their eyes; Princeton's ban on indoor smoking prompts and incendiary suit. New Jersey Law Journal 19 June 2000.

84 Toutant C. Princeton Encroached on state in enacting anti-smoking law; Judge strikes 3 month old ordinance challenged by smokers and restaurants. New Jersey Law Journal 4 September 2000.

85 Emery C. Kiesel asks softening of smoking ordinance. Providence JournalBulletin 22 October 2001:B-04.

86 Staff. Lawsuit challenges smoking ordinance. Providence Journal-Bulletin 9 June 2000:1C.

87 Staff. Second-hand smoke battle heats up for restaurants. Providence JournalBulletin 26 July 2000:2C.

88 Staff. Fallout in East Greenwich--GOP chief blasts council Republicans over handling of smoking ordinance. Providence Journal-Bulletin 30 November 2000:1C.

89 Harrington J. Judge: City smoking ban illegal. Helena Independent Record 4 December 2002.
90 Harrington J. Smoking battle resurfaces. Helena Independent Record 11 July 2003.

91 Staff. Headline: New England. The Providence Journal-Bulletin 11 November 2002:B-08

92 Staff. Around the towns. The Union Leader (Manchester NH) 14 January 2003:B1.

93 Meersman N. Justices hear arguments in Colebrook smoke ban. The Union Leader (Manchester NH) 11 July 2003:A1.

94 Staff. Towns, cities go further on smoking bans. The Union Leader (Manchester, NH) 19 November 2002:B4

95 Colquhouh L. Colebrook voters to revist issue of smoke-free dining. The Union Leader (Manchester, NH) 17 April 2002:A1

96 Smith S. Nassau butts ban goes up in smoke. New York Post 5 June 2003:024

97 Golden D. Nassau County Attorney's Office. Personal Interview with Meredith Nixon 2003.

98 Cockfield E. Steadfast about smoking ban; Nassau Dems fight pressure. Newsday (New York) 25 February 2003:A29.

99 Cockfield E. Businesses sue Nassau over smoking ban; see law as unconstitutional. Newsday (New York) 13 March 2003:A20

100 Cockfield E. Ruling clouds smoking bans; Nassau case could hurt NY law. Newsday (New York) 6June 2003:A26. 